\title{
PENGARUH CANDI CETHO SEBAGAI OBYEK WISATA SEJARAH TERHADAP KEHIDUPAN SOSIAL EKONOMI MASYARAKAT DESA GUMENG KECAMATAN JENAWI KABUPATEN KARANGANYAR
}

\author{
Danang Finantoko \& Abraham Nurcahyo*
}

\begin{abstract}
Abstrak
Penelitian ini bertujuan untuk mengetahui pengaruh Candi Cetho sebagai obyek wisata sejarah terhadap kehidupan sosial ekonomi masyarakat di Desa Gumeng Kecamatan Jenawi Kabupaten Karanganyar Tahun 2001-2012. Penelitian dilakukan selama 6 bulan, mulai Februari sampai dengan bulan Juli. Sumber data yang digunakan dalam penelitian ini adalah data primer dan sekunder. Metode pengumpulan data dengan menggunakan metode wawancara observasi dan dokumentasi. Dalam menganalisis data digunakan metode Analisis Interaktif dengan berpegangan pada tiga komponen yaitu: Reduksi data, Sajian data, kesimpulan-kesimpulan: penarikan/verifikasi. Dari hasil penelitian yang telah dilakukan diperoleh gambaran beberapa pengaruh Candi Cetho sebagai obyek wisata sejarah terhadap kehidupan sosial ekonomi di Desa Gumeng Kecamatan Jenawi Kabupaten Karanganyar. Sebelum dijadikannnya Candi Cetho sebagai obyek wisata sejarah, kehidupan sosial ekonomi masyarakat masih sangat rendah karena masyarakat masih tergantung dari bertani. Setelah Candi Cetho dijadikan sebagai obyek wisata pada masa orde baru. Berpengaruh terhadap kehidupan sosial ekonomi dalam memberikan lapangan pekerjaan kepada masyarakat sehingga meningkatkan kesejahteraan dan juga potensi desa. Tetapi kurangnya perhatian pemerintah dalam pengembangan Candi Cetho sebagai obyek wisata mengakibatkan pembangunan yang kurang bisa merata dan belum bisa dirasakan oleh masyarakat Desa Gumeng. Perbaikan jalan harus lebih diperhatikan oleh pemerintah agar memudahkan pengunjung untuk datang ketempat obyek wisata. Perkembangan sosial ekonomi masyarakat Desa Gumeng Kecamatan Jenawi Kabupaten Karanganyar juga meningkat dari tahun ke tahun. Hal ini dapat dilihat dari pendapatan perkapita penduduk yang relatif naik dari tahun ke tahun dan bertambahnya jumlah keluarga sejahtera dalam rentang waktu tahun 2001-2012.
\end{abstract}

Kata kunci: Candi Cetho, Sosial Ekonomi

\section{Pendahuluan}

Indonesia mempunyai banyak peninggalan hindu yang dapat digunakan sebagai wahana sejarah dan pariwisata, salah satu diantaranya adalah Candi Cetho yang merupakan tempat wisata di Indonesia yang masih bernuansa agama hindu dan digunakan sebagai tempat upacara keagamaan sampai saat ini. Candi Cetho (ejaan bahasa jawa : cetha ) merupakan sebuah candi bercorak agama Hindu peninggalan masa akhir pemerintahan
Majapahit (abad ke-15). Laporan ilmiah pertama mengenai candi cetho dibuat oleh Van de Vlies pada 1842. A.J. Bernet Kempers juga melakukan penelitian mengenai candi tersebut. Ekskavasi (penggalian) untuk kepentingan rekonstruksi dilakukan pertama kali pada tahun 1928 oleh Dinas Purbakala Hindia Belanda. Berdasarkan keadaannya ketika reruntuhannya mulai diteliti, candi ini memiliki usia yang tidak jauh dengan Candi Sukuh. Lokasi candi berada di Dusun Ceto, Desa Gumeng, 
Kecamatan Jenawi, Kabupaten Karanganyar, pada ketinggian $1400 \mathrm{~m}$ diatas permukaan laut.(sumber:

\section{http://id.wikipedia.org/wiki/Candi Ceto,}

Diunduh 7 februari 2012)

Sampai saat ini, komplek Candi Cetho digunakan oleh penduduk setempat yang beragama Hindu sebagai tempat pemujaan dan populer sebagai tempat pertapaan bagi kalangan penganut agama asli Jawa/Kejawen, selain itu Candi Cheto juga sebagai tujuan pariwisata Kabupaten Karanganyar.

Lokasi yang relatif dekat dengan objek wisata Candi Sukuh-Tawangmangu serta Telaga Sarangan membuat Candi Cetho sebagai salah satu tujuan tempat wisata sejarah yang banyak menyajikan panorama alam yang indah dan menawan. Maka menambah nilai lebih pada Candi Cetho sebagai tempat wisata sejarah dan menjadi daya tarik tersendiri bagi para pengunjung yang datang untuk berlibur dan menikmati keindahan alam yang memang menjadi pemandangan indah yang terdapat disekitar Candi Cetho.

Berbagai macam peninggalan bersejarah terdapat di Kabupaten Karanganyar, yang dijadikan sebagai cagar budaya guna untuk menjaga dan melestarikan warisan budaya. Sehingga dapat dinikmati oleh kalangan masyarakat dan pelajar. Karena benda cagar budaya merupakan kekayaan budaya bangsa yang penting bagi pemahaman dan pengembangan sejarah sebagai ilmu pengetahuan dan kebudayaaan.

Usaha dalam melestarikan hasil kebudayaan ini dilandasi sikap ingin berkembang maju yang merupakan syarat utama dalam ketahanan dan pemekaran kebudayaan Indonesia dengan menyaring masuknya kebudayaan asing sesuai dengan sifat keterbukaan dalam masa reformasi saat ini. Penyaringan itu agar kebudayaan asli Indonesia tidak terjerumus budaya barat. Karena hasil budaya di Indonesia banyak sekali ragam dan macamnya. Maka dari itu kita harus mencintai segala sesuatu yang ada di Indonesia.

Candi Cetho yang merupakan salah satu produk budaya Indonesia yang banyak menyimpan cerita-cerita sejarah dan juga masih digunakan sebagai tempat ibadah bagi sebagian penduduk setempat. Menjadikan Candi Cetho sebagai tempat tujuan wisata sejarah yang banyak dikunjungi oleh para wisatawan domestik maupun wisatawan mancanegara. Keberadaan Candi Cetho sebagai tempat wisata sejarah merupakan upaya pemerintah untuk menanamkan kepada masyarakat dan para pemuda rasa cinta untuk melestarikan budaya Indonesia. Sebab pariwisata dengan segala aktivitasnya mampu memberikan pengaruh yang cukup signifikan bagi perubahan masyarakat baik secara ekonomi, sosial maupun budaya. sehingga menuntut adanya perhatian yang lebih dari para pengambil kebijakan sektor 
pariwisata untuk mempertimbangkan kembali pola pengembangan kawasan wisata agar masyarakat sekitar lebih dapat merasakan manfaatnya.

Industri pariwisata dalam dekade terakhir ini banyak mendapatkan perhatian khusus dari pemerintah daerah karena mempunyai sumbangan dan kontribusi yang tidak sedikit terhadap pemasukan pendapatan dari wisatawan baik wisatawan domestik maupun wisatawan mancanegara. Pendapatan daerah dapat meningkat dengan adanya arus kunjungan wisatawan domestik, demikian juga dengan adanya kunjungan para wisatawan mancanegara yang secara kuantitatif ikut memberikan sumbangan devisa negara yang tidak sedikit sehingga banyak negara yang berlomba meningkatkan kualitas industri pariwisata untuk menarik perhatian para wisatawan domestik maupun mancanegara.

$$
\text { Peranan pariwisata dalam }
$$
pembangunan negara pada garis besarnya berintikan tiga segi, yakni segi ekonomis (sumber devisa, pajak-pajak), segi sosial (penciptaan lapangan kerja), dan segi kebudayaan (memperkenalkan kebudayaan kita kepada wisatawan). Ketiga segi tersebut tidak saja berlaku bagi wisatawan asing, tetapi juga untuk wisatawan domestik. Jadi bisa disimpulkan bahwa pariwisata adalah sebuah kegiatan ekonomi, sedangkan tujuan utama dari pengembangan pariwisata ialah untuk mendapatkan keuntungan dalam hal perekonomian, khususnya, bagi masyarakat maupun daerah (negara).

Uraian di atas bila dihubungkan dengan upaya pengembangan Candi Cetho sebagai obyek wisata sejarah akan menimbulkan berbagai dampak, termasuk kehidupan sosial ekonomi masyarakat sekitar candi. Masalah ini belum banyak mendapat perhatian dan belum ditulis. Untuk itu, maka penulisan masalah ini menarik dan perlu dilaksanakan.

\section{Tujuan dan manfaat penelitian}

Tujuan penelitian ini untuk mengetahui pengaruh Candi Cetho sebagai obyek wisata sejarah terhadap kehidupan sosial ekonomi masyarakat Gumeng Jenawi Karanganyar Tahun 2001-2011. Penelitian ini diharapkan bermanfaat sebagai berikut:

1. Bagi peneliti

Untuk menambah pengetahuan dan wawasan sejarah khususnya mengenai pengaruh candi cetho sebagai obyek wisata sejarah .

2. Bagi Masyarakat

Dapat digunakan sebagai wacana dan menambah pengetahuan. Dan mengenal sejarah candi cetho sebagai obyek wisata sejarah.

3. Bagi Prodi Sejarah FPIPS IKIP PGRI Madiun

Menambah acuan di perpustakaan tentang sejarah pendidikan yang dapat digunakan oleh mahasiswa IKIP PGRI Madiun untuk kajian ilmu sejarah dalam 
rangka konteks sejarah kontemporer dan pengembangannya.

\section{Tinjuan Pustaka}

\section{Pariwisata}

Pengertian pariwisata istilah pariwisata (tourism) baru muncul dimasyarakat kira-kira pada abad ke-18, khususnya sesudah revolusi industri di Inggris. Istilah pariwisata berasal dari dilaksanakanya kegiatan wisata (tour), yaitu suatu aktivitas tempat tinggal sementara dari seorang, diluar tempat tinggal sehari-hari dengan suatu alasan apa pun selain melakukan kegiatan yang bisa menghasilkan upah dan gaji.(Muljadi, 2009 : 8-9)

Menurut Muljadi (2009: 8-9 ) Pariwisata merupakan aktivitas, pelayanan atau produk hasil industri pariwisata yang mampu menciptakan pengalaman perjalanan bagi wisatawan. Unsur pembentukan wisatawan yang utama adalah adanya daya tarik dari suatu tempat tau lokasi.

Arti "pariwisata" belum banyak diungkapkan oleh para ahli bahasa dan pariwisata Indonesia. Kata " pariwisata" berasal dari dua suku kata, yaitu pari dan wisata. Pari berarti banyak, berkali-kali dan berputar-putar, sedangkan wisata berarti perjalanan atau bepergian. Jadi pariwisata berarti perjalanan atau bepergian yaang dilakukan secara berkali-kali atau berkeliling. Pariwisata adalah padanan bahasa Indonesia untuk istilah tourism dalam bahasa Inggris.

Nadjamuddin Ramly (2007:47) berpendapat bahwa "pariwisata" menjadi populer setelah digelar musyawarah nasional Tourisme II di tretes, 12-14 Juni 1958, istilah yang digunakan untuk "pariwisata" adalah "tourisme" yang berasal dari bahasa belanda. Sebagai pengganti istilah "tourisme" digunakan "dharmawisata" untuk perjalanan antarnegara (manca negara). Yang berjasa mengenalkan dan mempopulerkan kata pariwisata itu adalah Jenderal G.P.H. Djatikusumo yang waktu itu menjabat Menteri Perhubungan Darat, Pos, Telekomunikasi dan Pariwisata.

Menurut Nyoman S. Pendit (1994:34) pariwisata adalah salah satu industri baru mampu menghasilkan pertumbuhan ekonomi yang cepat dalam menyediakan lapangan kerja, peningkatan penghasilan, standar hidup serta menstimulasi sektor-sektor produktivitas lainnya. Selanjutnya, sebagai sektor yang kompleks, ia juga meliputi industri-industri klasik yang sebenarnya seperti industri kerajinan tangan dan cinderamata. Penginapan dan transportasi secara ekonomis juga dipandang sebagai industri.

Berdasarkan uraian di atas dapat disimpulkan, bahwa pariwisata memungkinkan suatu negara atau daerah 
mendapatkan gambaran yang nyata atas volume pendapatan nasional yang dihasilkan dari industri pariwisata. Apa pun dan kapanpun konsep yang dipergunakan oleh suatu negara di dalam melakukan kebijaksanaan industri pariwisatanya, yang jelas adalah adanya suatu pegangan yang dapat dipergunakannya. Pegangan inilah yang penting dan adanya pegangan ini suatu sistem statistik perpajakan pariwisata mudah dirumuskan, dan hasil perkiraan tiap tahunnya dapat dengan mudah diramalkan.

\section{Candi}

Istilah candi merujuk pada bangunan suci zaman Hindu-Budha di Indonesia. Di Jawa Timur bangunanbangunan tersebut, kecuali yang berbentuk gapura, di kenal sebagai cungkup. Istilah candi dikenal di Sumatera bagian selatan, seperti Candi Jepara di Lampung dan Sumatera bagian tengah, seperti candi bongsu dari gugusan Muara Takus. Di Sumatera Utara istilah yang digunakan adalah biaro, seperti pada gugusan candi-candi Padang lawas.

Di Kalimatan selatan dikenal dengan nama Candi Agung dekat Amuntai. Di Bali tidak didapatkan istilah candi seperti yang dimaknai di Jawa. Bangunan purbakalanya tidak disebut sebagai candi. (Sukmono,1974) dalam buku Bagoes Wirjomartono dkk
(2009:165). Dalam kamus Besar Bahasa Indonesia, candi diartikan sebagai banguna kuno yang dibuat dari batu,berupa tempat pemujaan tau penyimpanan abu jenazah raja-raja atau pendeta-pendeta hindu atau budha.

Dalam bahasa Sansekerta, candi adalah sebutan untuk Durga atau dewi maut candika, sedangkan candigreha atau candikagraha atau candikalaya dalam penamaan tempat pemujaan bagi dewi tersebut. Candi kemudian dikaitkan dengan bangunan kematian/pemujaan arwah (candikalaya) Dalam bahasa Jawa Kuno, candi atau cinandi atau sucandi berarti 'yang dikuburkan', sedangkan dalam pemahaman arkeologi, candi dapat dihubungkan dengan bangunan untuk pemakaman maupun pemujaan.

Dalam prasasti Prambanan, istilah candi dapat dikaitkan dengan graha (tempat), yakni siwagraha (tempat tinggal siwa-candi siwa prambanan). Dalam Negarakertagama dan pararaton dikenal pula istilah dharma, sudharma (dharma hajj), pura/puri (tempat) seperti wisesaputra, wisnubawanapura, bajrajinaparamitapuri yang dapat dikaitkan dengan percandian. Bagoes Wirjomartono dkk (2009:165)

Menurut N.J. Krom, pada mulanya candi merupakan suatu tanda peringatan dari batu, baik berupa tumpukan-tumpukan batu ataupun berupa banguna kecil yang didirikan di 
atas suatu tempat penanaman abu jenazah. Wardenar membuat membuat analisis mengenai candi sebagai makam, dengan mengambil contoh Candi Jalalunta di lereng Gunung Penanggungan. Di sana ia menemukan peti batu yang mempunyai sembilan kotak kecil yang serupa dengan tata mandala nawasanga di Bali dan di dalamnya terdapat sisa-sisa abu pembakaran serta sisa-sisa tulang terbakar, pada tengahnya terdapat cupu emas yang berisi mata uang emas, kepingan emas dan perak. (Sukmono,1974) dalam buku Bagoes Wirjomartono dkk (2009:166)

Berdasarkan uraian diatas, maka dapat disimpulkan bahwa candi merupakan suatu bangunan yang dibuat pada masa Hindu-Budha yang bertujuan sebagai tempat penyimpanan abu jenasah para raja-raja. Selain itu candi juga digunakan sebagai tempat pemujaan bagi umat Hindu.

\section{Kehidupan Sosial Ekonomi}

a. Sosial

Secara termologi sosiologi berasal dari bahasa yunani, yakni kata socius dan logos. Socius yang berarti kawan, berkawan, ataupun bermasyarakat. Sedangkan logos berarti ilmu atau dapat juga berbicara tentang sesuatu. Dengan demikian, secara harfiah istilah sosiologi dapat diartikan ilmu tentang masyarakat
(Spencer dan Inkeles, 1982: 4; Abdulsani, 1987: 1). Oleh karena itu, sosiologi sebagai disiplin ilmu yang mengkaji tentang masyarakat maka cakupannya sangatlah luas, dan cukup sulit untuk merumuskan suatu definisi yang mengemukakan keseluruhan pengertian, sifat, dan hakikat yang dimaksud dalam beberapa kata dan kalimat. Dengan kata lain, suatu hanya dapat diapakai sebagai suatu pegangan sementara saja. ( Dadang supardan, 2007: 69) Pada umumnya, sosiologi berkosentrasi bukan pada pemecahan masalah, tetapi kemunculan ilmu sosiologi ini dimaksudkan untuk membuat manusia sebagai makluk rasional ikut aktif ambil bagian dalam gerakan sejarah, suatu gerakan yang diyakini memperlihatkan arah dan logika yang belum diungkapkann oleh manusia sebelumnya. Karena itu, sosiologi dapat membuat manusia merasa seperti di rumah sendiri di dunia yang lebih mampu mengendalikan diri mereka dan secara kolektif dan tidak langsung kondisi mereka harus beraktivitas.

Dengan kata lain, soiologi diharapkan akan menemukan kecenderungan historis ddari penelaahan masyarakat moderndan memodifikasikan. Sosilogi membantu pengatiran dan pengembangan proses 
pemahaman yang mendasar, baik terencana maupun spontan. Sejak dari awal, sosiologi mengasumsikan bahwa tidak semua tranformasi modern itu bermanfaat atau diharapkan.

Karena itu, sosiologi harus memberi peringatan kepada publik di semua lapisan, khususnya di tingkat pembuat kebijakan, tentang adanya bahaya yang tersembunyi di balik proses yang tidak terkendali itu. Sosiologipun harus memberikan jalan keluar untuk mencegah terjadinya proses yang tidak di inginkan tersebut, atau mengusulkan cara memperbaiki kerusakan yang terjadi.(Dadang Supardan, 2007:71)

Ferdinand Tonies (18551936) memperkirakan pergantian sejarah, di mana gemainscaft jaringan ikatan parsial dan impersial-memiliki tujuan tertentu dan kontraktual. Email Durkheim ( 1855-1917) memfokuskan analisisnya pada ternd histori atas pembagian progresif dari tenaga kerja, dan karena itu akan menambahkan kompleksitas sosial secara keseluruhan. Ia mengajukan sebuah model masyakat integrasikan, pertama melalui solidaritas mekanik dari sekmen yang sama, kemudian melalui solidaritas irganik dari kelas dan golongan yang berbeda-beda, namun saling ketergantungan satu sama lain.

Max Weber (1864-1920) menghadirkan modernitas terutama dari sudut pandang rasionalisasi serta mengabaikan semua bidang kehidupan sosial, pikiran, dan kebudayaan.dan semakin banyaknya tindakan yang dilakukan berdasarkan kalkulasi rencana serta mengabaikan tindakan irasional, maupun berdasarkan aturan adat istiadat.

George Simmel (1859-1918) menekankan pergerakan dari hubungan kulitatif dan terdiferensiasi ke arah hubungan kuantitatif yang seragam. Menggarisbawahi peran baru yang semakin meningkat yang dimainkan oleh kekuatan yang semakin universak dan mandiri. Contoh yang paling baik adalah institusi keuangan dan aliran pemikiran kategoris abstrak (Bauman,2000:1028) Dalam buku Dadang Supardan (2007:71)

Apabila dahulu sosiologi terutama berhubungan dengan semua aspek stabilitas, reproduksi diri, dan perulangan, di mana dengan jalan atau cara mengamankan semuas aspek tersebut (perhatian utama dari sistem Talcot Parsons yang pernah dominan dan menarik perhatian dari fungsionalisme struktural) maka kini perhatian beralih kepada studi 
inovasi. Dipahami bahwa setiap tindakan adalah semacam kerja kreatif, meskipun pemahaman ini selalu mengambil penjelasan dari pola-pola yang telah ada dan bermakna.

Penekanan pun telah jauh bergeser daqri penelitian hukumdan keteraturan lainnya ketindakan yang lebih dinamis. Tindakan tidak lagi dianggap sebagai kepastian, tetapi lebvih sebagai kemungkinan, setiap tindakan adalah kreasi yang unik, dan karena itu sebenarnya tidak dapat diprediksi. Keraguan pun diajukan kepada nilai prediksi dari statistik. Diakui bahwa sebagian bear fenomena yang sering terjadi tidak selalu merepresentasikan trend masa depan.

Akibatnya, tampak atau tidaknya kreteria yang jelas untuk mengantisipasi konsekuensi dari kejadian, dampak, dan durabilitasnya. Oleh karena itu, untuk menilai signifikasinya, hal itu pada gilirannya mengakibatkan erosi objek atau atau daerah studi sosiologi yang pernah menjadi pusat perhatian dan bersifat khusus. Karena sosiologi tidak lagi berhubungan dengan konflik dasar, hubungan utama, atau proses yang mengarahkan maka tidak jelas mengapa beberapa topi tertentu, aktor atau peristiwa harus diberikan prioritas oleh para sosiologi.

$$
\text { Perhatian para sosialogi }
$$

bergeser dari ruang kendali (dari isuisu seperti damak negara, dominan kelas, dan sebagainya) ke interaksi sehari-hari dan mendasar, ke tingkat akar rumput dari realitas, ke apa yang aktor lakukan satu sama lain dan kepada mereka sendiri, didalam konteks interaksi langsung.

Di bawah pengaruh argumen alfred Schutz yang menyatakan bahwa "dunia di dalam jangkauan" memberikan arketiap untuk para kator suatu model dari semua"kesemestaan makna" yang lain (schutz, 1982), diasumsikan bahwa keahlian dan pengetahuan esensial secar reflektif atau tidak, yang disebabkan para aktor di dalam kehidupan sehari-hari mereka, pada akhirnya bertanggungjawab atas apa yang dianggap trend global dan impersonal atau bertahanya sruktur objektif (Bauman, 2000:1013) Dalam buku Dadang Supardan(2007:72)

(1989:4) berpendapat bahwa sosiologi merupakan studi sistematik tentang interaksi sosial manusia. Titik fokus perhatiannya terletak pada hubungan-hubungan dan pola-pola interaksi, yaitu bagaimana pola-pola tersebut tumbuh-kembang, 
bagaimana dipertahankan, dan juga bagaimana mereka berubah.(Damsar, 2009: 1)

b. Ekonomi

Ekonomi merupakan kata serapan dari bahasa Inggris, yaitu economiy. Sementara kata economy itu sendiri berasal dari bahasa yunani, yaitu oikonomike yang berarti pengelolahan rumahtangga. Adapun yang dimaksud dengan ekonomi sebagai pengelolahan rumahtangga adalah suatu usaha dalam pembuatan keputusan dan pelaksanaannya yang berhubungan dengan pengalokasian sumber rumahtangga yang terbatas diantara berbagai anggotanya, dengan mempertimbangkan kemampuan, usaha, dan keinginan masing-masing.

Oleh karena itu, suatu rumah tangga selalu diharapkan pada banyak keputusan dan pelaksanaannya. Harus diputuskan siapa anggota keluarga yang melakukan pekerjaan apa dengan imbalan apa dan bagaimana melaksanakannya (Damsar, 2009: 910). Istilah Ekonomi berdasar dari bahasa yunani, yaitu oikos namos atau oikonomia. Secara bahasa, oikos namos atau oikonomia sulit diterjemahkan, tetapi orang-orang barat menerjemahkannya dengan management of bousebold or estate (tata laksana rumah tangga atau pemilikan) (Sastradipoera, 2001:4).
Pengertian ini ditujukan untuk menggambarkan usaha manusia untuk memilih dan memanfaatkan sumber daya guna memenuhi kebutuhan hidupnya. Perbuatan memilih inilah yang menjadi inti ilmu ekonomi (Ace Partadireja, 1993: 3). Dalam perbuatan memilih ini terdapat sejumlah prinsip dan pegangan teori ekonomi (Supardi,2011: 110-111).

Menurut Albert L. Meyers, ilmu ekonomi adalah nilmu yang mempersoalkan kebutuhan dan pemuasan kebutuhan manusia. Kata kunci dari definisi ini adalah kebutuhan dan pemuas kebutuhan. Kebutuhan, yaitu suatu keperluan manusia terhadap barang dan jasa yang sifat dan jenisnya sangat bermacam-macam dalam jumlah yang tidak terbatas. Pemuas kebutuhan memiliki ciri-ciri terbatas.

Aspek yang kedua inilah menurut Lipsey (1981:5) menumbulkan masalah dalam ekonomi, yaitu adanya suatu kenyataan yang senjang karena kebutuhan manusia terhadap barang dan jasa jumlahnya tak terbatas, sedangkan dilain pihak barang dan jasa sebagai alat pemuas kebutuhan sifatnya langka atau terbatas.l itulah sebabnya manusia di dalam hidupnya selalu berhadapan dengan kekecewaan maupun ketidakpastian. 
Definisi ini tampaknya begitu luas sehingga kita sulit memahami secara spesifik (Dadang Supardan,2007:366). Ahli ekonomi lainya, yaitu J.L.Meij mengemukakan bahwa ilmu ekonomi adalah ilmu tentang usaha manusia ke arah kemakmuran (Abdullah, 1992:6). Pendapat tersebut sangat realistis karena ditinjau dari aspek ekonomi di mana manusia sebagai makhluk ekonomi (Homo Ekonomicus), pada hakikatnya mengarah pada pencapaian kemakmuran.

Kemakmuran menjadi tujuan sentral dalam kehidupan manusia secara ekonomi, sesuai yang dituliskan pelopor liberalisme ekonomi, yaitu Adam Smith dalam bukunya An Inquiry into the nature and cause of the wiealth of natiaons tahun 1976. Namun, bagaimana manusia mencapai kemakmurannya memang tidak dijeaskan dalam definisi yang dikemukakan meij tersebut(Dadang Supardan,2007:366367). Kemudian, Samuelson dan Nordhaus (1990:5) mengemukakan bahwa ilmu ekonomi merupakan studi tentang perilaku orang dan masyarakat dalam cara menggunakan sumber daya yang langka dan memiliki beberapa alternatif penggunaan dalam rangka memproduksi berbagai komoditi, kemudian menyalurkannya baik saat ini maupun di masa depan kepada berbagai individu dan kelompok yang ada dalam suatu masyarakat.

Menurut Samuelson, ilmu ekonnomi merupakan ilmu pilihan. Ilmu yang mempelajari bagaimana orang memilih pengunaan sumbersumber daya produksi yang langka atau terbatasuntuk memproduksi berbagai komoditi dan menyalurkannya diberbagai anggota masyarakat untuk segera dikomsumsi. Jika disimpulkan dari tiga pendapat di atas, walaupun kalimatnya berbeda-beda, namun tersirat pada hakikatnya ilmu ekonomi merupakan usaha manusia untuk memenuhi kebutuhannya dalam mencapai kemakmuran yang diharapkan, dengan memilih pengguna sumber daya produksi yang sifatnya langka atau terbatas tersebut. Dengan kata lain ilmu ekonomi merupakan suatu disiplin tentang aspek-aspek ekonomi dan tingkah laku manusia (Dadang Supardan, 2007:367).

Kita tidak dapat membayangkan, bagaimana bagaimana kehidupan manusia jika tidak berada dalam masyarakat (sosial). Sebab semua individuindividu tidak dapat hidup dalam keterpencilan selama-lamanya. 
Manusia membutuhkan satu sama lain untuk bertahan hidup sebagai manusia. Kesalingketergantungan ini menghasilkan bentuk kerja sama tertentu yang bersifat ajeg dan menghasilkan bentuk masyarakat tertentu, sebuah keniscayaan. Dengan demikian, manusia adalah makhluk sosial. (Dadang Supardan,2007 : 2526) Di dalam kehidupan manusia tidak bisa terlepas dengan peristiwaperistiwa ekonomi, atau peristiwaperistiwa ekonomi selalu timbul didalam kehidupan manusia. Hal tersebut disebabkan di satu pihak kebutuhan manusia tidak terbatas di lain pihak alat pemuas kehidupan manusia terbatas adanya.

$\begin{array}{cccc} & \text { Kebutuhan } & \text { manusia yang } \\ \text { tidak } & \text { terbatas inilah yang }\end{array}$
menimbulkan permintaan atas barang dan jasa yang sangat diperlukan di dalam kehidupan manusia. Seberapa jauh kemampuan permintaan kebutuhan manusia atas barang dan jasa sangat tergantung dari pendapatan yang mereka peroleh. Semakin tinggi pendapatan seseorang semakin besar kemampuan permintaan atas barang dan jasa.

Keterbatasan alat pemuas kebutuhan manusia menumbuhkan kegiatan penawaran atas barang dan jasa. Penawaran atas barang daan jasa guna memenuhi kebutuhan manusia merupakan aktifitas manusia dalam kegiatan dunia usaha. Barang dan jasa apa yang akan dihasilkan, siapa yang menghasilkan dan bagaimana barangbarang didistribusikan sangat dipengaruhi oleh sistem ekonomi yang dianut oleh suatu negara. Secara teoritis masing-masing sistem ekonomi yang ada selalu berusaha untuk mencapai kemakmuran seluruh masyarakat, walaupun kenyataannya menimbulkan kemiskinan bagi sebagian besar masyarakat (Hartomo,1990:285-286.)

\section{Metode Penelitian}

1. Tempat dan waktu penelitian

Lokasi atau tempat yang dijadikan obyek penelitian adalah Candi Cetho di Desa Gumeng Kecamatan Jenawi Kabupaten Karanganyar. Hal ini didasari pada suatu kenyataan bahwa pengaruh Candi Cetho sebagai objek wisata sejarah terhadap kehidupan sosial ekonomi masyarakat setempat belum pernah diangkat. Tepatnya berada di Desa Gumeng Kecamatan Jenawi Kabupaten karanganyar. Penelitian dilakukan selama 6 bulan yaitu dimulai pada bulan februari 2012 sampai bulan juli 2012.

a. Sumber data

Pemahaman mengenai berbagai macam sumber data merupakan bagian yang sangat penting bagi peneliti karena ketepatan memilih dan menetukan jenis sumber data yang 
akan menentukan ketepatan dan kekayaan data atau kedalaman informan yang diperoleh (H.B.Sutopo,2006:56). Dalam penjelasan ini, sumber data dalam penelitian kulitatif ada 5 macam yaitu informan, tempat, benda, peristiwa, serta dokumen atau arsip.

2. Teknik pengumpulan data

Ada 3 teknik pengumpulan data, adapun teknik pengumpulan data tersebut adalah wawancara (interview), observasi, dan dokumentasi.

3. Keabsahan data

Teknik keabsahan temuan dalam penelitian ini menggunakan teknik triangulasi. "Dalam teknik pengumpulan data, triangulasi diartikan sebagai teknik pengumpulan data yang bersifat menggabungkan dari berbagai teknik pengumpulan data dan sumber data yang telah ada",(Sugiyono,2010: 83)

4. Analisis data

Analisis data yang digunakan adalah analisis Model Analisis Interaktif (HB.Sutopo, 2006:120)

\section{Hasil Penelitian}

\section{A. Sejarah Pembangunan Candi Cetho}

Candi Cetho berada di Dusun Cetho, Desa Gumeng, Kecamatan Jenawi, Kabupaten Karanganyar tepat dilereng gunung lawu. Lokasi Candi Cetho berada diketinggian 1.400 meter diatas permukaan laut. Akses jalan untuk menuju lokasi candi ini beraspal sempit dan berkelok. Lingkungan alam yang masih terjaga keindahanya mendukung keberadaan Candi Cetho sebagai tempat wisata.

Candi cetho dibangun pada abad ke 15 pada akhir kerajaan Majapahit yang dipimpin oleh rajanya, $\mathrm{R}$. Brawijaya V. Bangunan Candi Cetho berupa punden berundak dengan 9 teras yang terdapat gapura disetiap terasnya. Diteras pertama merupakan halaman candi, anda bisa melihat pemandangan disekitar kompleks Candi Cetho. Diteras kedua anda akan menemukan petilasan dari Kyai Ageng Krincing Wesi yang merupakan tokoh dari dusun cetho sendiri. Diteras ketiga anda akan menemukan phallus yang menjadi symbol Siwa yang berbentuk alat kemaluan dengan panjang 2 meter. Banyak relief - relief yang akan anda temukan diteras keempat, memasuki teras kelima dan keenam anda akan menjumpai tempat yang digunakan untuk upacara keagamaan.

Diteras ketujuh terdapat sebuah Arca Sabdopalon dan Nayagenggong abdi dalem yang merupakan penasehat R.Brawijaya. Diteras kedelapan anda akan menemukan Arca Phallus Kuntobimo, Arca R.Brawijaya juga bisa anda lihat disini, yang melambangkan suri tauladan dan raja yang berbudi luhur. Diteras yang terakhir merupakan tempat untuk memanjatkan doa, yang 
mempunyai luas 1,5 meter.(wawancara: Sucipto, 12 Juli 2012).

Pembangunan Candi Cetho ini merupakan keinginan R.Brawijaya $\mathrm{V}$ untuk melestarikan agama Hindu agar tidak hilang dengan adanya agama baru (islam) dikarenakan juga R.Brawijaya V tidak mau masuk agama Islam yang dianjurkan menantunya (Raden Patah) sebagai penguasa Kadipaten Demak.(wawancara: Sucipto, 12 Juli 2012)

\section{B. Lokasi Obyek Wisata Candi Cetho}

Secara administratif Desa

Gumeng Kecamatan Jenawi Kabupaten karanganyar yang dibatasi oleh: sebelah Utara Desa Jenawi, sebelah Selatan Desa Segorogunung, sebelah Barat Desa Kemuning, sebelah Timur Desa Anggrasmanis. Wilayah Desa Gumeng merupakan dataran tinggi, dengan luas 1502,6665 Ha. Letak Desa Gumeng yang berada di daratan tinggi menyebabkan penduduk Desa Gumeng mayoritas bermatapencaharian sebagai petani. Tanaman yang cocok ditanam di desa ini adalah tanaman sayuran dan produk holtikultura. Selain tanaman tersebut, Desa Gumeng juga dikelilingi oleh kebun teh yang sangat luas dan indah dipandang mata.

Masyarakat Gumeng menyadari keberadaan Candi Cetho sebagai obyek wisata, hal ini dapat dibuktikan dari setiap pengunjung yang datang ke Candi
Cetho masyarakat menyambutnya dengan ramah sekali, ada juga masyarakat yang menfaatkan kesempatan dengan berjualan di lokasi Candi Cetho maka secara tidak langsung dapat memberikan keuntungan tersendiri kepada masyarakat didekat objek wisata Candi Cetho.(wawancara: Sucipto, 12 juli 2012)

Kondisi Candi Cetho Objek Wisata saat ini masih perlu adanya pembenahan serta perbaikan atas semua fasilitas yang ada dalam sekitar Candi Cetho tersebut, untuk melakukan pembenahan itu pihak pengelola sendiri mengajukan dana kepada dinas purpakala dan pariwisata yang mengelola Candi Cetho.(wawancara: Kasmin,12 juli 2012)

Kebijakan pemerintah dengan menyediakan lahan untuk tempat berjualan bagi masyarakat desa Gumeng dalam ikut serta memajukan pariwisata Candi Cetho sebagai salah satu tujuan wisatawan baik domestik maupun mancanegara

\section{Pengembangan Wisata Candi Cetho dari Tahun 2001-2012}

1. Sarana dan prasarana yang ada di objek wisata Candi Cetho

Sarana umum fasilitas yang disediakan disekitar objek wisata Candi Cetho antara lain adalah:

a. Pembangkit tenaga listrik

b. Jaringan jalan raya beraspal 
c. Penyediaan air bersih langsung dari sumber mata air pegunungan

Prasana yang ada di objek wisata Candi Cetho antara lain adalah:

a. Puri Saraswati

Disebelah atas komplek Candi Cetho untuk menyambangi Puri Dewi Saraswati. Harus keluar dari pintu samping, naik lebih tinggi lagi ke atas bukit. Sekitar 300 meter kemudian sampailah di puri yang lebih mirip seperti sebuah taman ini. Bangunan utamanya adalah lapangan terbuka berlantai batu. Sebuah kolam dengan patung Dewi Saraswati berdiri anggun di atasnya. Dengan latar belakang pohon-pohon pinus, patung Dewi Ilmu Pengetahuan sumbangan dari Propinsi Bali ini nampak memancarkan aura magis tersendiri.

b. Candi Kethek

Candi ini berada disebuah hutan pinus milik Perhutani, untuk menuju ke candi kethek hanya bisa dilakukan dengan berjalan kaki saja sekitar 15 menit dikarenakan akses jalan hanya berupa jalan setapak kecil, licin jika hujan dan disebelah berupa jurang yang dalam. Perjalanan cukup melelahkan dan harus hati-hati apabila tidak ingin terpelesat jatuh ke jurang. Dalam bahasa jawa Kethek adalah kera, di lokasi candi ini tidak ditemukan gerombolan kera liar yang hidup di hutan ini. Nama kethek diberikan karena penduduk setempat mempercayai bagian atas dari candi ini menyerupai Hanoman, tokoh pewayangan berwujud kera putih

c. Sendang

Di sebelah kanannya terdapat sebuah jalan kecil menuju ke Sendang Pundi Sari yang dulunya berfungsi sebagai tempat penyucian diri sebelum sembahyang di candi.

d. Penginapan

Penginapan disediakan sebagai tempat istirahat bagi wisatawan mancanegara ataupun domestik yang ingin menikmati suasana malam di candi cetho yang mempunyai pemandangan yang menarik dan mempesona bagi wisatawan.

e. Toilet

Dikomplek wisata juga disediakan kamar mandi dan WC bagi para wisatawan sebagai salah satu fasilitas yang ada di objek wisata Candi Cetho.

f. Lahan tempat parkir

Ditempat wisata Candi Cetho merupakan objek wisata yang ramai dikunjungi para wisatawan mancanegara maupun domestik karena itu jasa lahan tempat parkir sangat penting demi kenyaman pengunjung agar merasa nyaman dan tenang dalam berkunjung karena kendaraannya terjamin keamanannya. 
2. Ketenagakerjaan

$$
\text { Dalam pengembangan }
$$

pariwisata, tenaga kerja yang mempunyai loyalitas dalam merawat dan menjaga objek wisata. Sangat dibutuhkan demi kemajuan Candi Cetho sebagai objek wisata yang banyak dikunjungi para wisatawan mancanegara maupun domestik. banyak juga masyarakat sekitar yang bekerja di objek wisata Candi Cetho.

Dengan adanya objek wisata Candi Cetho masyarakat Desa Gumeng mendapatkan penghasilan tambahan. Dan juga objek wisata Candi Cetho tersebut dapat menciptakan lapangan kerja dan mengurangi pengangguran (wawancara : Sucipto, 12 juli 2012)

3. Pemasaran objek wisata Candi Cetho Posisi Kabupaten Karanganyar sangat strategis karena merupakan kawasan yang berbatasan langsung dengan Jawa Timur dan merupakan Masih di Jalur Tawangmangu-Sarangan, terdapat candi selain Candi Sukuh yang lokasinya tidak jauh dari Candi Cetho. Hal ini memudahkan para pengunjung untuk menuju komplek wisata Candi Cetho.

Untuk mempromosikan pihak pengelola melakukan usaha yang menjadikan Candi Cetho dapat dikenal dikalangan masyarakat umum. Promosi tersebut menggunakan perjalanan umum, setiap sudut kota dipasang papan yang berisi tentang objek wisata candi cetho (wawancara, Kasmin, 12 juli 2012)

D. Kondisi Sosial Masyarakat Desa Gumeng Kecamatan Jenawi Kabupaten Karanganyar

Perkembangan masyarakat pada umunya selalu diwarnai dengan lompatan-lompatan status anggota masyarakat. Kondisi sosial semacam itu dinamakan mobilitas sosial, yaitu suatu gerakan dalam struktur sosial, yang memiliki pola-pola tertentu yang mengatur organisasi suatu kelompok manusia. Gerakan sosial dimaksudkan sebagai perpindahan individu atau objek sosial dari kedudukan sosial kedudukan yang lebih lainnya dan tidak sederajat.

Kehidupan sosial masyarakat Desa Gumeng Kecamatan Jenawi Kabupaten Karanganyar pada kurun waktu tahun 2001-2011 dapat kita lihat dari beberapa unsur diantaranya adat istiadat, sistem norma, pola interaksi sosial, struktur sosial, dan pola pergaulan atau gaya hidup.

Mata pencaharian masyarakat Desa Gumeng adalah bertani sayur dan memelihara hewan ternak. Kegiatan pertanian biasanya berupa mengolah tanah dan tanaman hingga masa panen. Dalam mengerjakan lahan pertanian mereka masih menggunakan peralatan yang sederhana seperti cangkul, dan sabit. Dalam memilih pupuk bagi tanaman, mayoritas petani di Desa 
gumeng masih memanfaatkan pupuk kompos yang didapatkan dari kotoran hewan ternaknya sendiri. Pupuk kompos ini bagi petani juga dirasa lebih bagus daripada pupuk kimia yang dapat merusak tanah (wawancara dengan Padmulyono)

Warga Desa Gumeng ingin melestarikan peralatan yang sederhana sebagai upaya menghemat biaya dalam bertani namun tidak menolak peralatanperalatan yang baru asal tidak merusak alam terutama tanah. Bila mereka tidak bekerja di kebun, maka aktivitas yang dilakukan adalah mencari rumput bagi hewan ternak.

Jumlah pengrajin souvenir atau cinderamata di Desa Gumeng hanya 3 orang saja. Mereka ini mempunyai keterampilan membuat kerajinan tangan berbahan baku dari kayu. Wisatawan yang singgah di Candi Cheto akan ditawarkan koleksi cinderamata yang diolah berdasarkan tradisi dan kebudayaan masyarakat. Jenis cinderamata yang dihasilkan dengan bahan dasar kayu bertuah berupa tongkat, gelang, tasbih, tongkat komando, dan stik drum. Pengrajinnya bukan orang biasa, namun tokoh adat yang dituakan dan dipercaya memiliki keahlian khusus yang dikaruniakan Tuhan. Infrastruktur jalan menuju kawasan candi sudah baik, sehingga memperlancar perjalanan wisatawan menuju objek. Akses infrastruktur jalan ini merupakan wewenang pemerintah propinsi. Di beberapa lokasi ditemukan banyak jalan yang saat ini mulai rusak serta berlubang, sementara itu jika pemerintah kabupaten berniat memperbaiki maka persyaratannya adalah harus mengajukan proposal terlebih dahulu ke tingkat propinsi. Dalam kesempatan yang tidak terjadwal, secara spontan dan swadaya masyarakat menambal jalan dengan semen.

Berbagai jenis alat transportasi yang disediakan sebagai sarana angkutan menuju kawasan Candi Cheto diantaranya adalah bus dalam ukuran kecil sebagai angkutan umum, mobil pribadi, truk (alat transportasi angkutan barang dan sayur-mayur), serta sepeda motor. Kondisi jalan menuju objek wisata Candi Cetho pada umumnya menanjak. Sistem penerangan jalan pada malam hari belum tersedia secara merata sehingga perjalanan di waktu malam terkendala.

Namun, meskipun sarana penerangan belum tersedia secara baik, selama ini masyarakat Gumeng tidak mengalami kejadian merugikan seperti pencurian, penjambretan, begal atau rampok. Bagi masyarakat Gumeng, perjalanan malam hari dianggap aman dan tidak menghambat mobilitas sosial mereka. Kegiatan rutin yang terkait dengan adat Desa Gumeng antara lain 
slametan atau kondangan. Bentukbentuk tradisi yang bersifat turun temurun juga dilakukan para leluhur mereka, seperti upacara 1 Suro atau sering disebut Suronan; Bersih Desa atau sering disebut Mondosiyo yang dilaksanakan setahun dua kali, dan Ruwahan yang dilaksanakan pada bulan ruwah. Pada acara tradisi tersebut di atas penduduk menggunakan sesaji seperti masyarakat Jawa pada umumnya seperti tumpeng, ingkung, dan segala macam ubarampe yang digunakan untung persembahan kepada para leluhur. Upacara keagamaan di Desa Gumeng adalah sebagai berikut

a. Hari raya Nyepi

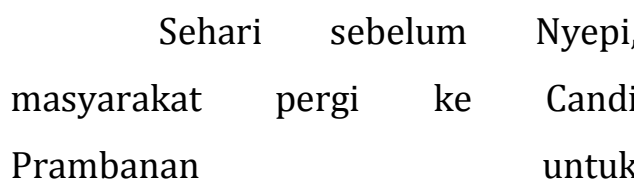
bersemedi/bersembahyang bersama masyarakat Hindu dari berbagai daerah dengan maksud menyambut tamu agung. Apabila ada umat yang berhalangan untuk beribadah di Prambanan, maka mereka tetap bias beribadah di pelataran Candi Cheto. Toleransi antar umat beragama di Desa Gumeng terlihat pada saat perayaan Nyepi, karena yang beragama Islam pun ikut merayakan dengan membawa sesaji ke pelataran candi. Sebaliknya, pada hari raya Idul Fitri warga yang beragama Hindu ikut merayakan dengan ikut saling maaf- memaafkan atau sungkem ke tiap warga. Pada saat perayaan Nyepi memang tidak ada pentas seni yang diselenggarakan, alat kesenian yang digunakan untuk mengiringi upacara adalah gamelan yang disebut CengCeng, dan kostum yang digunakan adalah adat jawa.

b. Galungan

Upacara galungan bagi umat Hindu di Desa Gumeng dilaksanakan selama dua kali dalam satu tahun. Pelaksanaannya di plataran candi sebagai tempat bersembahyang bagi seluruh warga. Upacara galungan ini dilaksanakan pada hari Rabu kliwon menurut kalender Hindu dari Bali

c. Upacara Saraswati

Upacara Hari Saraswati adalah di Pura Saraswati, letaknya kira-kira 300 meter, belakang Candi Cheto. Upacara ini dilaksanakan pada hari sabtu legi setiap bulan menurut kalender Hindu dari Bali.

d. Upacara Adat Mondosiyo

Upacara adat mondosiyo dilaksanakan oleh masyarakat sebagai rasa syukur kepada Danyang Kyai Grincing Wesi. Upacara ini untuk bersih desa, agar masyarakat dan alam di Desa Gumeng bisa bebas dari segala macam musibah. Upacara mondosiyo dilaksanakan setahun sekali pada hari Selasa Kliwon tahun wuku menurut kalender Hindu di 
pelataran Candi Cheto. Pada malam harinya menanggap wayang kulit, biaya untuk menanggap wayang kulit diperoleh dari swadaya masyarakat. Upacara mondosiyo apabila sudah dilakukan tujuh kali berturut-turut maka pada pelaksanaan yang kedelapan upacara ini ditiadakan/diliburkan. Jadi upacara yang ketujuh merupakan upacara mondosiyo yang paling besar atau lain dari pada sebelumnya.

e. Dawuhan

Upacara adat dawuhan dimaksudkan untuk menghormati atau bersyukur kepada Mbah Cikal Bakal yaitu nenek moyang mereka yang dipercaya sebagai pemberi air bagi kehidupan warga Desa Gumeng. Dana untuk upacara adat dawuhan juga berasal dari swadaya masyarakat karena dalam kepercayaan, masyarakat pantang meminta bantuan dari pemerintah, akan tetapi kalau pemerintah/pihak-pihak lain ingin memberi mereka bantuan, mereka tidak menolak.

f. Ruwahan

Seperti masyarakat Jawa
lainnya, warga masyarakat Desa
Gumeng juga masih mempertahankan
upacara/tradisi ruwahan. Tradisi ini
dilaksanakan di pemakaman Desa
tersebut dengan didahului acara tabur
bunga. Setelah itu tumpeng yang

dibawa dimakan bersama-sama dengan seluruh masyarakat yang hadir di tempat itu. Pelaksanaannya pada tanggal 15 ruwah. Biaya ruwahan ditanggung masing-masing keluarga. Apabila orang tua mereka yang meninggal dimakamkan di desa tersebut berjumlah 2 orang maka keluarga tersebut membuat dua buah tumpeng, demikian juga warga yang lain juga sama dalam membuat jumlah tumpeng yang harus diserahkan kepada pemuka agama dusun tersebut.

g. Suranan (1 Suro)

Upacara untuk menyambut tahun baru Jawa. Masyarakat Desa Gumeng berkumpul di rumah tokoh masyarakat atau kepala Desa semalaman untuk mengikuti tirakatan.

h. Wetonan

Wetonan adalah upacara untuk mengenang hari lahir (weton) dan rasa syukur kepada Tuhan karena masih diberi keselamatan. Upacara ini dilaksanakan setiap bulan sesuai hari lahirnya masing-masing (wawancara, Sucipto, 12 juli 2012)

Beragam tradisi dan adat istiadat yang dimiliki masyarakat Gumeng merupakan modal sosial sehingga perlu dilestarikan. Keberadaan komunitas Hindu Cheto di kawasan candi merupakan daya magnetik dalam 
menarik perhatian wisatawan. Pada sisi ekonomi, kehadiran wisatawan berdampak positif meningkatkan kesejahte-raan masyarakat.

Perhatian dari pemerintah daerah, universitas, badan-badan atau lembaga sosial kemasyarakatan lainnya semakin intensif dalam rangka memberdayakan potensi masyarakat Ceto. Bentuk dukungan dari pihak luar antara lain berupa pelatihan, seperti misalnya kursus pemandu wisata (tour guide), sablon dan kerajinan.

F. Kondisi Ekonomi Masyarakat Desa Gumeng Kecamatan Jenawi Kabupaten Karanganyar

Dari kondisi Sosial Ekonomi
masyarakat dapat diketahui semakin
meningkat. Penghasilan hanya dari
sektor pertanian, untuk memenuhi
kebutuhan sehari-hari sebagian
masyarakat berpindah dari sektor
pertanian ke sektor perdagangan yang
dinilai lebih menguntungkan. Hal ini
dikarenakan masyarakat desa gumeng
ingin mendapatkan keuntungan lebih.

Keterlibatan masyarakat lokal sebagai staf karyawan di kompleks candi menunjukkan semakin intensifnya pemberdayaan bagi masyarakat Desa Gumeng. Peran masyarakat dalam pengelolaan kawasan candi setidaknya merupakan sarana melestarikan tradisi dan adat istiadat masyarakat Desa Gumeng. Petugascandi mensosialisasikan aturan berjualan di sekitar candi berdasarkan nilai-nilai sosial masyarakat Desa Gumeng. Contohnya, penjajakan makanan di kawasan Candi Cheto sudah mendapat informasi bahwa ketika berjualan tidak diijinkan memaksa calon pembeli untuk berbelanja di warungnya. Wisatawan mancanegara termasuk konsumen yang jarang membeli di warung sekitar candi, alasannya adalah pedagang tidak menyediakan barangbarang yang diperlukan wisatawan manca, khususnya masalah hidangan makanan.

Setiap hari raya Hindu, para pedagang menutup warungnya karena harus mengikuti prosesi ibadah yang diselenggarakan di Candi Cheto atau di Pura sekitarnya. Dalam melaksanakan tanggungjawab sebagai pegawai dinas purbakala, selama ini petugas candi tidak menemukan hambatan yang berat dalam melayani wisatawan karena setiap ada permasalahan selalu dapat diatasi.

Para pedagang mulai berdagang di sekitar Candi Cheto sejak didirikannya Puri Saraswati tahun 2004. Kawasan candi ramai dikunjungi wisatawan khususnya pada hari Sabtu dan Minggu. Umumnya kedatangan wisatawan adalah ke lokasi Candi Cheto, setelah itu menuju Puri Saraswati. Di sepanjang jalan menuju Puri, terdapat warung-warung sederhana sebagai tempat berjualan makanan dan cinderamata. Ketika 
berjalan melewati warung-warung tersebut, para pedagang tidak menawarkan barang dagangannya. Alasannya, para pedagang merasa malu jika ketika menjual makanan harus menawarkan dagangan kepada pembeli. Rata-rata semua pedagang bersikap demikian. Sikap tersebut tidak diatur dalam ajaran Hindu, tetapi muncul dari kesadaran para pedagang yang merasa malu jika mereka harus menawarkan dagangan. Para pedagang percaya bahwa rejeki diatur Tuhan. Jika ada pembeli yang mampir ke suatu warung, artinya rejeki dari Yang Maha Kuasa diberikan kepada pemilik warung itu, pedagang lain tidak iri hati (wawancara dengan Endah Sriwahyuni, Paikem dan Dwi Anggrawati, 12 juli 2012)

Kehadiran

wisatawan

berdampak positif meningkatkan kesejahteraan masyarakat. Perhatian dari pemerintah daerah, universitas, badan-badan atau lembaga sosial kemasyarakatan lainnya semakin intensif dalam rangka memberdayakan potensi masyarakat Gumeng. Bentuk dukungan dari pihak luar antara lain berupa pelatihan, seperti misalnya kursus pemandu wisata (tour guide), sablon dan kerajinan.

Ada dua penginapan yang menjadi pioner sekaligus percontohan bagi munculnya penginapan lain, yaitu Mekarsari dan Adem Ayem. Sayang sekali kemudian Penginapan Adem Ayem tidak beroperasi lagi. Ketiga penginapan itu mendapat bantuan dari Diparta Karanganyar sebesar 10 juta untuk membiayai pembangunan kamar. Jasa penginapan ramai dikunjungi wisatawan saat hari libur dan hari besar agama Hindu. Tamu dari Surabaya maksimal menginap dua malam. Mereka umumnya wisatawan yang akan beribadah di candi. Sebulan sekali ada organisasi/arisan pemilik penginapan.

Kegiatan yang dilakukan adalah untuk menentukan harga/tarif kamar. Harga kamar: Rp. 100.000,- mendapat fasilitas bed, meja rias, kamar mandi dalam, dan TV. Harga Kamar Rp. 65.000,mendapat fasilitas bed dan kamar mandi dalam. Setiap bulan masing-masing pemilik penginapan membayar iuran keamanan sebesar Rp. 20.000,- dikelola oleh Pak Ngadino untuk disetorkan ke Polsek. Keperluan memperbaharui ijin usaha ke diparta Karanganyar dilakukan selama lima tahun sekali. (wawancara dengan Ngadino, 12 juli 2012)

Kaum muda Hindu berkumpul setiap dua minggu sekali untuk memperdalam ajaran Hindu serta mengisi waktu dengan latihan bersama Misalnya seperti belajar mengoperasikan laptop dengan program-program tertentu yang belum dikuasai beberapa kaum muda, seperti program Corel Draw. Sebelumnya sudah sering diadakan 
pelatihan untuk pemuda Desa Gumeng seperti misalnya pelatihan sablon, tetapi masyarakat tidak siap mengembangkan keahliannya dalam bentuk bisnis sablon kaos, dsb.

Masyarakat terkendala, misalnya pada tidak tingkat kunjungan wisatawan yang tidak menentu dan sulit diprediksi, sehingga kadang usaha yang dijalankan tidak menghasilkan keuntungan bahkan pada akhirnya macet dan gulung tikar. Pada akhirnya warga masyarakat merasa pesimis dan enggan berdagang. Para pemuda Hindu jarang menikmati acara televisi di waktu senggangnya. Setiap hari minggu pagi aktif mengikuti kerja bakti di kampung.

\section{Pembahasan}

Pariwisata candi cetho merupakan bagian yang penting dalam sistem perekonomian masyarakat khususnya di Dusun Cetho. Kegiatan perekonomian rakyat yang berupa pertanian merupakan sumber pendapatan yang sangat berarti bagi masyarakat. Dalam perkembangan objek wisata Candi cetho lebih efektif bila melibatkan seluruh komponen yang ada di masyarakat sekitar objek wisata Candi Cetho. Pegawai dan pengelolaan objek wisata dapat mengambil dari tenaga penduduk sekitar Desa Gumeng, tanpa mengambil tenaga dari luar daerah atau pegawai tetap. Mereka mendapatkan penghasilan dari bekerja diobjek wisata tersebut.

$$
\text { Berkaitan dengan kajian }
$$

pustaka dalam Bab II dan paparan data pada Bab IV, secara umum keberadaan Candi Cetho sangat membantu dalam peningkatan ekonomi masyarakat utamanya masyarakat di Desa Gumeng Kecamatan jenawi Kabupaten Karanganyar. Masyarakat sangat terbantu dengan keberadaan objek wisata Candi Cetho baik dari sisi pemenuhan lapangan kerja.

A. Pengaruh Candi Cetho Sebagai Objek Wisata Sejarah Terhadap Kehidupan Sosial Ekonomi Masyarakat

Keberadaan Candi Cetho sebagai salah satu objek wisata sejarah dapat memberikan lapangan kerja yang cukup luas bagi masyarakat Desa Gumeng. Salah satunya adalah dengan mendirikan lahan bisnis yang dikelola pribadi masyarakat disekitar objek wisata Candi Cetho. Kegiatan dalam mengembangkan usaha sendiri merupakan upaya dari masyarakat untuk mempunyai penghasilan tambahan dan tidak tergantung lagi dari hasil pertanian. Beberapa usaha pribadi ada juga yang mendapatkan bantuan pemerintah yaitu penginapan dan sebagaian para pedagang.

Beberapa pengaruh sosial dan ekonomi yang dapat dibahas pada penelitian ini adalah sebagai berikut: 
a. Sosial.

Sebagaimana telah diuraian pada Bab II yaitu tentang manusia adalah makhluk sosial (Dadang Supardan, 2007:25-26). Masyarakat kita hidup ini merupakan sebuah kebersamaan yang penting membantu kita untuk mencapai tujuan-tujuan pribadi tertentu.

1) Dampak Sosial Positif

Dengan adanya objek wisata Candi Cetho banyak berpengaruh terhadap kehidupan sosial masyarakat. Selain itu Candi Cetho juga masih digunakan sebagai tempat sembayang bagi penduduk Desa Gumeng yang sebagaian besar menganut Agama Hindu. Bahkan bila hari raya agama Hindu banyak penganut agama Hindu dari luar kota yang datang untuk beribadah di Candi Cetho.

Kehidupan masyarakat Desa Gumeng menjadi lebih baik dengan keberadaan Candi Cetho sebagai objek wisata. Banyak masyarakat yang bekerja di objek wisata Candi Cetho yang dahulu sebagai menggantungkan dari bertani beralih menjadi pedagang ataupun pegawai yang direkrut oleh Dinas Purbakala dan pemerintah daerah.

2) Dampak Sosial Negatif

$$
\text { Dalam pengembangan }
$$

pariwisata kurangnya dukungan dan bantuan dari pemerintah pusat maupun daerah dalam pengembangan usaha ataupun pembangunan jalan. Dan tidak adanya alat transportasi untuk mencapai lokasi objek wisata Candi Cetho, sehingga menjadi kendala bagi para pengunjung yang tidak mempunyai kendaraan pribadi untuk mencapai lokasi objek wisata.

b. Ekonomi

$$
\text { Sebagaimana telah diuraian }
$$
pada Bab II bahwa di dalam kehidupan manusia tidak bisa terlepas dengan peristiwa-peristiwa ekonomi, atau peristiwa-peristiwa ekonomi selalu timbul didalam kehidupan manusia. (Hartomo,1990:285-286.) Hal tersebut disebabkan di satu pihak kebutuhan manusia tidak terbatas di lain pihak alat pemuas kehidupan manusia terbatas adanya.

1) Dampak Ekonomi Positif

$$
\text { Beralihnya sebagian }
$$

masyarakat dari pertanian menjadi pedagang dan sebagaian masyarakat yang bekerja di objek wisata Candi Cetho. Menunjukkan bahwa pariwisata mempunyai dampak ekonomi yang besar bagi masyarakat sekitar.

Dalam Bab IV sudah dibahas bahwa pengaruh ekonomi dengan adanya objek wisata Candi Cetho. Beralihnya sebagian masyarakat yang dahulu menggantungkan hidupnya dari bertani menjadi pedagang untuk mencukupi kebutuhan kehidupannya. Masyarakat mulai merasakan 
keuntungan objek wisata Candi Cetho dengan mengembangkan usaha yang dikelola sendiri yaitu penginapan, toilet/WC, lahan parkir, berdagang. Usaha ini didirikan karena ingin mendapatkan keuntungan tambahan selain dari pertanian.

2) Dampak Ekonomi Negatif

Keberadaan objek wisata Candi Cetho memang dapat memberikan keuntungan tersendiri bagi masyarakat Desa Gumeng. Penghasilan dapat diliat dari ramainya pengunjung, jadi tidak setiap hari mendapatkan penghasilan yang stabil. Bila pengunjung ramai maka pendapatan juga meningkat dan bila pengunjung sepi tidak ada pendapatan yang masuk.

\section{Simpulan dan Saran}

\section{A. Simpulan}

Berdasarkan hasil penelitian dapat disimpulkan, bahwa pengaruh Candi Cetho sebagai obyek wisata sejarah terhadap kehidupan sosial ekonomi masyarakat Desa Gumeng Kecamatan Jenawi Kabupaten Karanganyar. Adalah sebagai berikut:

Bahwa objek wisata sejarah Candi Cetho merupakan salah satu objek wisata yang banyak dikunjungi wisatawan mancanegara maupun domestik dan salah satu objek wisata yang ada di Kabupaten Karanganyar. Berpengaruh terhadap kehidupan sosial ekonomi masyarakat Desa Gumeng, dahulu penduduk Desa Gumeng menggantungkan kehidupannya dari bertani. Tetapi setelah dijadikannya Candi Cetho sebagai objek wisata memberikan perubahan dalam kehidupan sosial ekonomi. Masyarakat banyak yang bekerja dan membangunan tempat usaha disekitar Candi Cetho.

Keberadaan candi Cetho sebagai obyek wisata memberikan pengaruh terhadap kehidupan sosial ekonomi masyarakat di Desa Gumeng Kecamtan Jenawi Kabupaten Karanganyar yang memberikan lapangan pekerjaan yang luas bagi masyarakat disekitar Desa Gumeng. Penyerapan tenaga kerja di objek wisata Candi Cetho tidak banyak, tetapi pengembangan lapangan kerja baru pada kegiatan-kegiatan yang bersifat menunjang seperti kegiatan pedagang, tukang parkir dan penjaga loket.

\section{B. Saran}

Berdasarkan hasil penelitian dan simpulan di atas yang diperoleh maka dapat dikemukakan implikasi dari penelitian ini adalah sebagai berikut bahwa objek wisata Candi Cetho masih banyak masalah-masalah yang muncul agar dapat dinikmati masyarakat Candi Cetho yang selama ini belum pernah bisa sepenuhnya merasakan dari pengembangan Candi Cetho sebagai Objek Wisata. Dengan berorientasi dari hasil penelitian pada hasil penelitian 
tersebut diatas, maka penulis mempunyai saran dan harapan sebagai berikut:

1. Pemerintah Kabupaten Karanganyar, agar selalu memberikan perhatian terhadap objek wisata Candi Cetho yang merupakan salah satu pariwisata andalan yang ada di Kabupaten Karanganyar.

2. Kepala Desa Gumeng, agar selalu memberikan pengarahan terhadap masyarakatnya untuk selalu menjaga dan melestarikan budaya yang ada di Candi Cetho sebagai tempat tujuan wisata tersebut.

3. Bagi masyarakat Gumeng agar ikut serta dalam menjaga dan merawat salah satu peninggalan sejarah yang sangat berharga dan masih menjadi tempat ibadah bagi umat Hindu.

\section{Daftar Pustaka}

Bagoes wirjomartono dkk. 2009. Sejarah Kebudayaan Indonesia Arsitektur. Jakarta: Rajawali pers

Basri MS.2006. Metodologi Penelitian Sejarah. Jakarta : Restu Agung Jakarta
Damsar. 2009. Pengantar Sosiologi Ekonomi Jakarta: Kencana

Dadang Supardan. 2007. Pengantar Ilmu Sosial Sebuah Kajian Pendekatan Struktual. Bandung: Bumi Aksara

Hartomo, Arnicun Aziz. 1990. Ilmu Sosial Dasar. Jakarta : Bumi Aksara

H.B. Sutopo. 2006. Metodologi Penelitian Kualitatif. Surakarta: Universitas Sebelas Maret.

Muljadi. 2009. Kepariwisataan dan perjalanan. Jakarta: PT RajaGrafindo Persada

Nadjamudin Ramly.2007. Pariwisata Berwawasan Lingkungan Belajar Dari Kawasan Wisata Ancol. Jakarta: Grafindo Khazanah Ilmu

Nyoman S Pendit. 1994. Ilmu Pariwisata Sebuah Pengantar Perdana. Jakarta : Pt Pradnya Paramita

Monografi Desa Gumeng Kecamatan Jenawi Kabupaten Karanganyar

Sukardi. 2003. Metodologi Penelitian Pendidikan Kompetensi Dan Prateknya. Yogyakarta : Pt Bumi Angkasa

Sugiyono. 2010. Metode Penelitian Kuntitatif dan Kualitatif $R \& D$. Bandung: Alfabeta

Supardi. 2011. Dasar-Dasar Ilmu Ekonomi yogyakarta: Ombak

Sukmono.1973. Pengantar Sejarah Kebudayaan Indonesia 2. Jakarta : kanisus

http://id.wikipedia.org/wiki/Candi_Ceto, Diunduh 7 februari 2012. 